\title{
Iwona Święch
}

Polskie Stowarzyszenie Inwentaryzatorów Muzealnych

Polskie Towarzystwo Ludoznawcze Oddział w Krakowie

\section{0 muzealnym magazynie rzeczy}

Rem tene, verba sequentur. Trzymajmy się (sensu) rzeczy, słowa się znajdą — to mogłoby być motto do wystawy Porzadek rzeczy. Magazyn Piotra B. Szackiego czynnej już od pięciu lat w Państwowym Muzeum Etnograficznym w Warszawie ${ }^{1}$. Niniejszy tekst jest odautorską refleksją na temat jej założeń oraz kłopotów rozmaitej natury (zarówno technicznych, jak i merytorycznych), jakich od początku przysparzała ${ }^{2}$.

Przywołane na wstępie sławne zdanie Katona z Nauk dla syna wskazuje na fakt, iż obserwowany we współczesnej humanistyce (ale też w sztuce) już od dłuższego czasu szczególny „powrót” do rzeczy w istocie nie jest niczym nowym. Fenomenologiczne poszukiwania pierwotnych sensów rzeczy, czy rozważania o ich mityzacji, idea bricolage czy też przedmioty jako dzieła sztuki od readymade Duchampa po artystyczne widzimisię Kuśmirowskiego - wszystkie te działania dotyczą pytań o rzeczy i o to co jest ich istotą, co stoi za rzeczą, a raczej za jej metaforą, a jeszcze zasadniej — za nieustannie nakładającą się metaforycznością.

\footnotetext{
${ }^{1}$ Wystawa stała Porządek rzeczy. Magazyn Piotra B. Szackiego. Kuratorzy: Iwona Święch, Jan Święch, współpraca: Małgorzata Jaszczołt, Aleksander Robotycki, Mariusz Raniszewski, Joanna Bartuszek, realizacja: zespół Państwowego Muzeum Etnograficznego w Warszawie pod kierunkiem Adama Czyżewskiego.

${ }^{2}$ Mam tu na myśli zmagania zespołu dotyczące samej koncepcji wystawy odchodzącej od „oswojonej” opowieści o kulturze wsi i próby „doklejania” do niej fragmentów według całkiem innego porządku, rezygnację z katalogu, nieukończenie prac nad materiałem filmowym, czy też prozaiczne problemy ze szwankującym sprzętem elektronicznym i katalogiem zbiorów Musnet. Nie wszystkie z tych kłopotów udało się rozwiązać.
} 
To są też pytania, które stawia sobie muzealnik, badacz kultury materialnej i kolekcjoner, a takim badaczem był Piotr Szacki; jego fascynacja codziennością i spojrzenie na niepowtarzalność rzeczy, będące punktem wyjścia do prekursorskich w muzealnictwie etnograficznym wystaw, były impulsem do powstania tej wystawy. Zaprezentowanie tego punktu widzenia, tej filozofii i tego kolekcjonerskiego dzieła, wydało nam się ważne i znaczące dla historii muzealnictwa. Także dlatego, że Piotr Szacki tworzył i realizował swoją ideę dotyczącą przedmiotów codziennych na długo przed wspomnianym „zwrotem” ku rzeczom, na bardzo długo zanim Deyan Sudjic podsumował to lapidarnie:

Nasze związki z tym co posiadamy, nigdy nie są proste. To skomplikowana mieszanka przemyślności i niewinności. Przedmioty nie są w żadnym razie niewinne, jak to sugerował Berger. I właśnie dlatego są zbyt interesujące, by o nich nie mówić [Sudjic 2013: 11].

To był główny powód, dla którego przyjęliśmy propozycję dyrektora Adama Czyżewskiego - kuratorstwa wystawy w PME.

Były także inne powody. Niemniej ważne było nasze przekonanie, że spełnione są warunki, aby wytwory dawnych umiejętności mogły zaistnieć w tym specyficznym pokazie. Chodziło o to, że przestrzeń magazynów muzealnych została już odkryta przez twórców różnych dziedzin, że powszechna stała się swoboda odniesień kojarzonych z rzeczami i bezpruderyjny do nich stosunek, że istnieje odpowiednie ukierunkowanie wrażliwości. Innymi słowy: stan gotowości do odbioru takiego komunikatu jest na tyle ukształtowany, że nasza wystawa — rekwizytornia może stać się właściwym stymulatorem do poznania nieistniejącej już kultury chłopskiej, do specyficznych doznań. Pozycję takich stymulatorów poświadcza klasyczny wątek proustowskich magdalenek, przywoływany zresztą przez Piotra Szackiego w jego rozważaniach nad muzealnictwem etnograficznym [Szacki 1991: 136]. Kwalifikacje kustosza, jego biegłość w postrzeganiu treści zawartych w formie i substancji przedmiotu, swoboda skojarzeń i trafnych odniesień nie są przywilejem wyłącznie tego zawodu. Uznaliśmy, iż zatrzymamy się wobec tego na kreacji magazynu rzeczy — skarbca przedmiotów. Wpisując się w antropologię współczesności, przedstawiliśmy rodzaj słownika, bazy do interpretacji, nie formułując żadnych wyjaśniających narracji. Chcieliśmy stworzyć możliwość szczególnego doświadczenia: odnajdywania drogi do własnej pamięci, do fragmentów przeszłości zapisanych w tymże własnym magazynie, do poszukiwań ich źródła, po prostu do własnych 


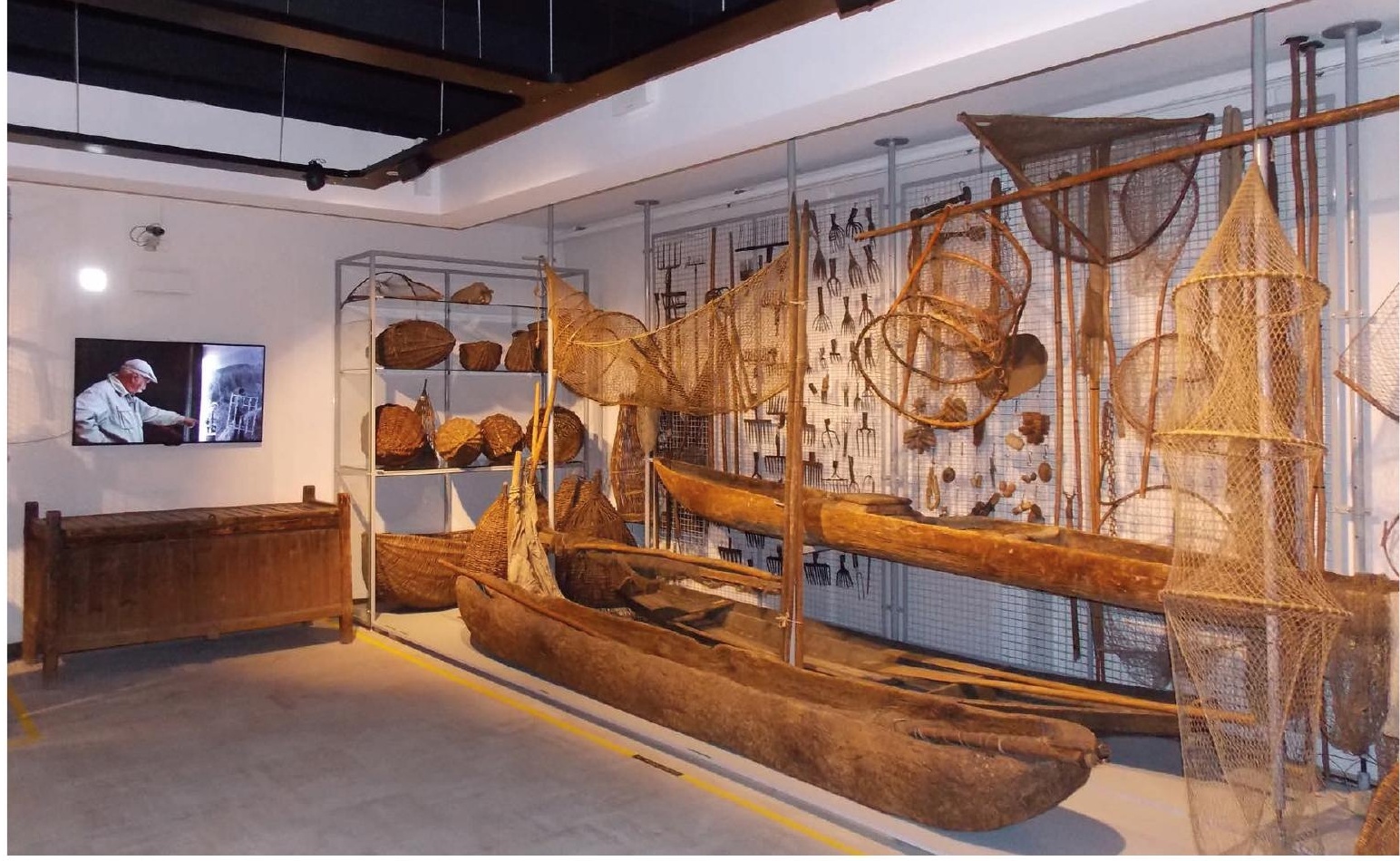

Il. 1. Fragment wystawy (Fot. Jan Święch)

wspomnień. Albo wyobrażeń. Porzucając antropologiczne roszczenia do interpretacji, zaproponowaliśmy widzowi niesformalizowany osobisty ogląd. Indywidualne patrzenie oparte o swój własny bagaż wiedzy, doświadczeń, emocji, wrażliwości, umieszczając jednocześnie w obszarze wystawy zestaw wspomagających narzędzi.

Ale najbardziej może oczywistym, w każdym razie dla etnologa, powodem pozostaje specyfika nieistniejącej już tradycyjnej kultury chłopskiej epoki przedprzemysłowej, funkcjonującej jeszcze w enklawach do lat 70. XX wieku, kultury związanej z naturą w sposób trudny dziś do wyobrażenia. Jak każda inność zawsze wzbudzała zainteresowanie, rodząc stereotypy, ale też wnikliwe studia. Świat przedmiotów był zwykle ich scenografią, istotną, niemniej pozostającą w tle. Nasza wystawa to kolejna wypowiedź o realiach wiejskiego świata tamtych czasów, ale taka w której scenografia staje się przedstawieniem właściwym, niemal kompletnym. Niemal — bowiem zorganizowane w kolekcje przedmioty potrzebują dopełnienia w sferze umiejętności: układów ciała, wyspecjalizowanych nawyków ruchowych, perfekcyjnych gestów, dzięki którym narzędzie staje się precyzyjnym instrumentem, przedmiot zostaje doskonale uzbrojony w ciało człowieka myślącego. Ten niematerialny kontekst przedmiotów przedstawiają filmy (nie tylko Piotra Szackiego), przywołując jednocześnie dźwięki tamtego świata jak terkotanie kołowrotków, chlupot śmietany 
grupujących przedmioty konieczne dla perspektywy historycznej, społecznej, obyczajowej i geograficznej, uwzględniając (co warte podkreślenia) kontekst etniczny.

Drugi model opublikował w 1928 r. Kazimierz Moszyński [Moszyński 1928: 1-78] Jego koncepcja koncentrowała się na dokumentacji określonego regionu etnograficznego poprzez tworzenie zestawów przedmiotów niezbędnych do ekspozycyjnej prezentacji tej kultury zarówno materialnej jak i duchowej i społecznej. Ta propozycja kierowana zasadniczo do muzeów regionalnych stała się podstawą organizacji licznych działów etnograficznych w muzeach polskich w okresie przed-i powojennym.

Kolejny model zarysowała, a następnie rozwinęła Cezaria Baudouin de Courtenay Ehrenkreutzowa [1926:1-28 oraz 1933: 82-93]. W jej koncepcji kluczem do doboru przedmiotów do kolekcji była ich funkcja ideologiczna rozumiana jako zdolność do obrazowania przemian, kontekstu wynikającego ze stosunku tworzywa do techniki wytwórczej. Kolekcję budowali pracownicy i studenci Zakładu Etnologii Uniwersytetu w Wilnie, tworząc Uniwersyteckie Muzeum Etnograficzne. Wojna przeszkodziła w pełnej realizacji tego projektu, a zgromadzone zbiory zostały rozproszone.

Ostatni model opracował, wzorując się osiągnięciami muzealnictwa skandynawskiego, i realizował właśnie Piotr Szacki, który głównie w latach 70. ubiegłego stulecia stworzył przemyślaną kolekcję z zakresu gospodarki podstawowej i rzemiosł. Dla wprowadzanego do kolekcji obiektu opracowywano

Il. 3. Fragment wystawy (Fot. Jan Święch)

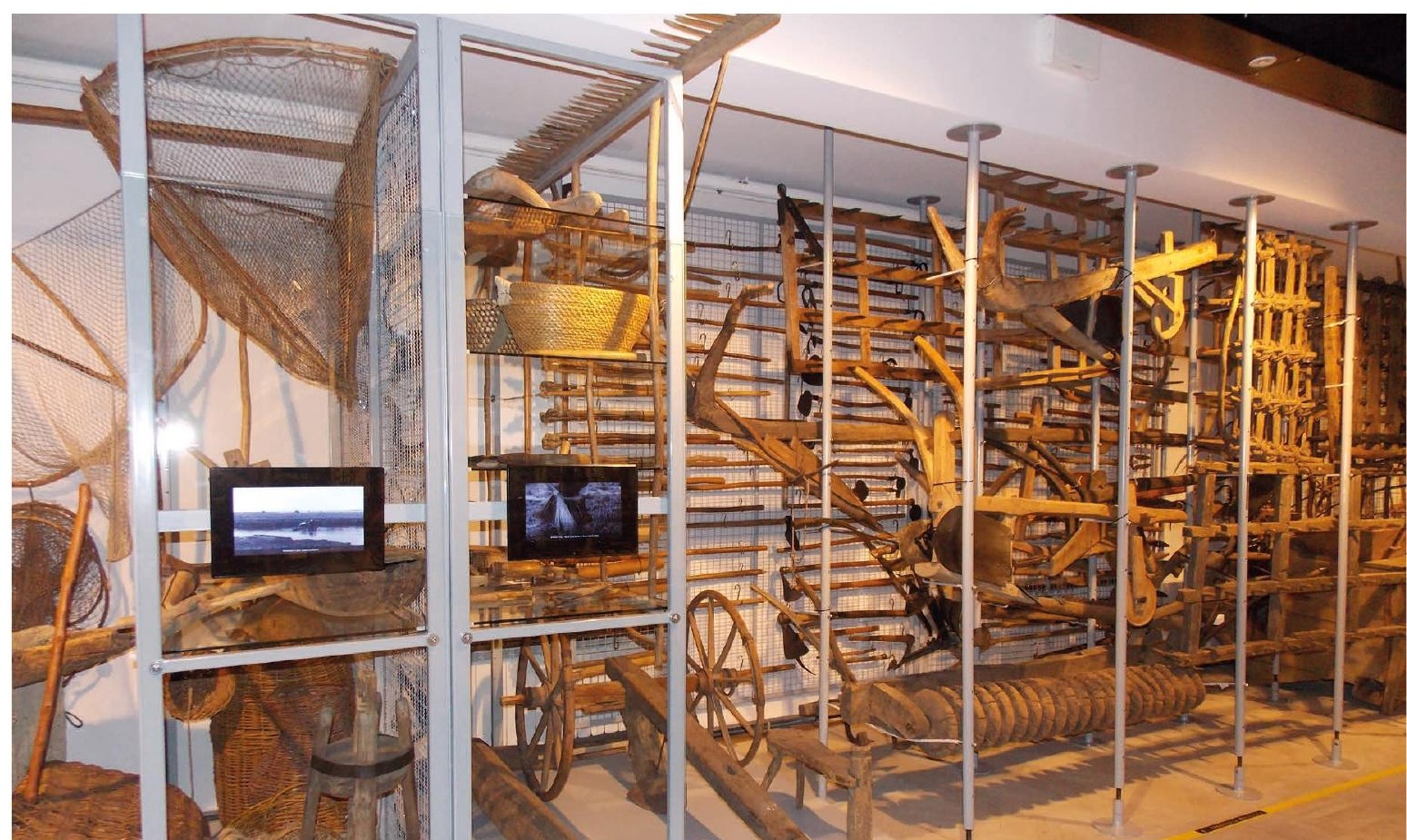


jego studium, metrykalną dokumentację obejmującą technologię wytwórczą, funkcjonowanie w systemie kultury, pojedynczą historię, podbudowaną zapisem filmowym. Wynikało to z przekonania, iż w procesie użytkowania i wytwarzania dopiero połączenie człowieka z przedmiotem, włącznie z odgłosami i uwalnianymi zapachami tworzy całościowy obraz.

Naszą wystawą postanowiliśmy powrócić do kolekcji i kolekcjonerstwa jako do źródła muzealnych spektakli wystawowych, do przedmiotów, które skutkiem wcielenia do muzealnych zbiorów stały się zabytkami. Ten szczególny akt podnoszenia najzwyklejszej nieraz rzeczy do takiej rangi angażuje nie tylko wiedzę i kompetencje muzealnika-kolekcjonera, ale często w równym stopniu emocje towarzyszące tej pracy, potencjał symboliczny rzeczy, całe dossier. Ten etap „pozyskiwania” przedmiotów do zbiorów można odnaleźć na wystawie w tekstach i fotografiach. Przede wszystkim jednak chodzi o etap muzealnej egzystencji rzeczy, przedmiotów już do kolekcji wcielonych. Na scenę wprowadzamy więc kulisy. Pokazujemy przedmioty takie, jakie muzealnik ogląda na co dzień, jak aktorów przed charakteryzacją, w garderobie, w szczególnym momencie pomiędzy życiem prywatnym a spektaklem. Przedmioty, które nie spełniają już swych zadań w kulturze, która je stworzyła, i nie odtwarzają dawnej roli w charakteryzacji scenograficznej wystawy. Czekają, są prawdziwe. Można wejść pomiędzy nie z własnym bagażem wiedzy, wspomnień, ciekawości, emocji, empatii. Na tym indywidualnym użyciu szczególnie nam zależało. Na trzymaniu się rzeczy, sprzed jakichkolwiek interpretacji.

Realizacja nie była łatwa, ale pomysły obecnych opiekunów kolekcji, kustoszy-magazynierów, dawnych współpracowników Szackiego, plastyków i informatyków były nie tylko inspiracją, ale też radością wspólnego myślenia. Szczęśliwie Szacki opisał swój magazyn bardzo precyzyjnie. Stworzył klasyfikacje przedmiotów obejmującą ponad 20 działów, z których każdy dzieli się na wiele podgrup. Zastosowane kryterium — rozumiane jako powód wprowadzenia przedmiotu do muzealnej kolekcji - to jego funkcja. Każdy przedmiot jest więc środkiem do uzyskania określonego efektu. I tak na przykład funkcja obręczy czy wątorników jest związana z tworzeniem beczki, a funkcją beczki jest przechowywanie czy też konserwacja żywności. Te przedmioty powinny się więc znaleźć w różnych częściach wystawy. Tak jest ułożony magazyn i to jest podstawowy wyróżnik i wyjątkowość tej wystawy spośród dotychczasowych prezentacji kultury materialnej, pokazujących te przykładowe przedmioty razem, w zespole 
dotyczącym bednarstwa. Koncepcja tej wystawy-magazynu skupia się na miejscu, jakie zajmował przedmiot w środowisku dawnej wsi ze względu na swoją przydatność. Ową kategorię, elementarną dla tej kultury, a raczej mało podkreślaną w tradycji wystawienniczej, ta ekspozycja ma unaoczniać. Specyficzną paralelą jest jednoczesne pokazanie miejsca, jakie ten sam przedmiot zajmuje w środowisku muzeum pośród innych rzeczy niekoniecznie podobnych, a nawet skrajnie różnych ale służących temu samemu. Od form zgrzebnych i byle jakich po arcydzieła precyzji i urody. Przy czym sam przedmiot jest traktowany nie tylko jako rzecz służąca do czegoś, ale też wytwór rąk ludzkich z tkwiącą w nim „czystą” myślą techniczną, nieprofesjonalną, niejako „art brut”.

Wystawa wychodzi jednak poza prezentację kolekcji rzeczy. Chodzi o pełnowymiarową formułę udostępnienia tej kolekcji, czyli demonstrację całego kontekstu dokumentacyjnego: jako entourage dla przedmiotu muzealnego. Wystawa korzysta w tym celu z multimediów. Przede wszystkim prezentuje tuż obok rzeczy - tak dziś docenione - niematerialne dziedzictwo kulturowe: wyspecjalizowane ruchy ludzkiego ciała wraz z „częścią pracującą”, czyli narzędziem, zapis wizualny dynamiki procesu technicznego wraz z jego dźwiękiem (w przyszłości nawet zapachem). Jednym słowem poprzednie, przedmuzealne „życie” rzeczy, ale ponadto proces tworzenia kolekcji od pracy w tzw. terenie po klasyfikacje muzealne.

Możliwości techniczne, ekonomiczne, zapewne także ideologiczne nie pozwoliły samemu Szackiemu na takie realizacje. Dziś stało się to możliwe i być może po raz pierwszy w muzealnictwie wystawa podejmuje takie wyzwanie. Być też może, że dość słaba wiedza o pracy muzealnika, zwłaszcza muzealnika-etnografa, a jednocześnie artykułowana chęć poznania tego szczególnego zajęcia zostanie dzięki tej wystawie poszerzona. Uwolniliśmy tę przestrzeń dla wszystkich, można do niej wracać wielokrotnie, oglądać dziwne przedmioty o dawno zapomnianych nazwach (oryginały!), szukać ich tutaj, wraz z całą o nich informacją, sprawdzić kompleksowe rozwiązywanie problemów jak transport czy utrzymywanie czystości.

Taka wielowarstwowość to główna cecha wystawy-magazynu. Informacje dotyczące prezentowanych na magazynowych półkach przedmiotów zapisane są w kioskach multimedialnych, stanowiskach komputerowych, pulpicie multimedialnym, cyfrowych ramkach, na teleekranie. W kioskach przy pomocy indeksu rzeczowego określony przedmiot i dane o nim można odnaleźć poprzez jego fotografię. Stanowisko komputerowe umożliwia 


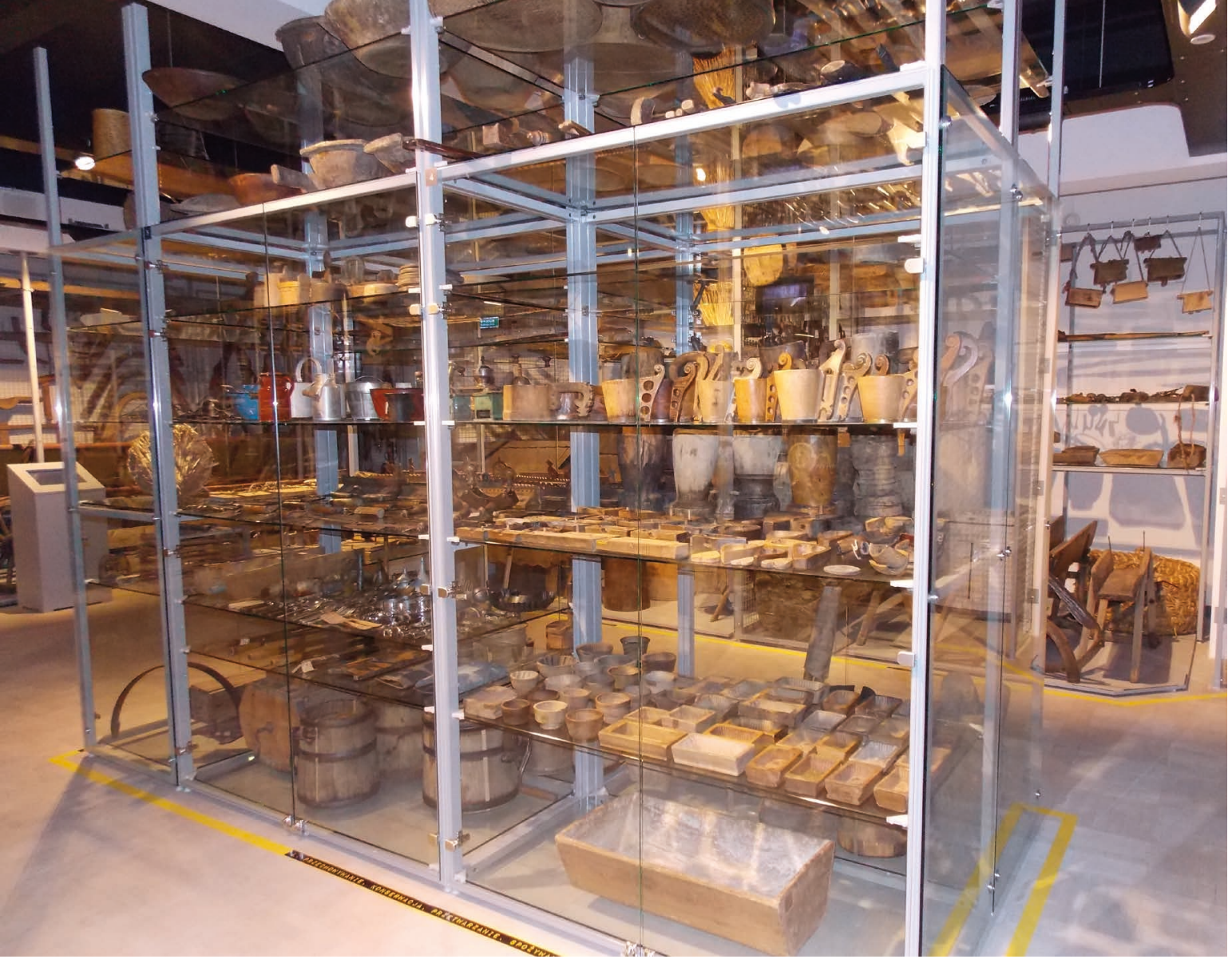

Il. 6. Fragment wystawy (Fot. Jan Święch)

a także - jak to ujmował sam Szacki - „względy autentyczności planu filmowego i merytorycznej zawartości zapisu /które/ grały tu jednak rolę pierwszorzędną, co nie pozostawało bez wpływu na urodę zdjęć i rytm narracji” [Chojnacki, Szacki 1989] mają ten niezwykły walor realizmu etnograficznego. Są obrazem dynamiki procesu technicznego, funkcjonowania człowieka i narzędzia, relacji pomiędzy czynnością a efektem. Tak potraktowany film jest częścią dokumentalnego zespołu jaki stanowi kolekcja rzeczy oraz dotyczące ich informacje pisane, serie fotografii, nagrania itp. W wielu wypadkach rekwizyty akcji filmu leżą na półkach wystawy-magazynu ponieważ weszły do zbiorów muzealnych. Tylko w takim kontekście te rejestracje osiągają pełny wymiar. Wystawa jest próbą wypracowania formuły umożliwiającej udostępnienie takich zespołów dokumentalnych szerszej publiczności. Filmów nie można jednak traktować tylko jak naświetlonej taśmy zawierającej wyłącznie zapis jakiś działań. Autorzy zwykle starają się ująć ową podstawową akcję w nieco szerszy plan sytuacyjny, nie ominąć interesującego kontekstu, nadać kompozycję. Filmy 
na wystawie roztaczają przed widzem świat sprzed lat ponad pięćdziesięciu. Wiejski świat ich bohaterów i badawczą rzeczywistość ich twórców, są w jakiejś mierze portretami konkretnych ludzi, utrwalają pewne cechy ich osobowości w sposób niekoniecznie zamierzony.

W założeniu to miała być wystawa rozwojowa, ciągle uzupełniana. Przede wszystkim o digitalizowane stopniowo dawne dokumentacje, filmy, nagrania, rzeczy po konserwacji. Ale także nowe nabytki, zdobywane informacje, napisane artykuły, opracowane fragmenty filmowe i fotograficzne. Powinna się nasycać i rosnąć jak każda kolekcja i kompendium wiedzy jej towarzyszące. Te wszystkie praktyki powinny też doskonalić i uczytelniać przyjętą formułę wystawienniczą, mającą ambicje wykraczające poza prostą prezentację magazynu, co w gruncie rzeczy (nomen omen) leży u źródeł kolekcjonerstwa: pokaz przedmiotów zgromadzonych wedle przyjętej zasady. Ten powrót do źródeł, do prezentacji magazynów (choć czasem opisywany jako przedsięwzięcie zupełnie nowatorskie) można obserwować w polskim muzealnictwie od kilku lat. Realizacje te zbliża do pewnego stopnia forma udostępniania zbiorów, jednak różni wszystko inne: powody takiego wyboru prezentacji, liczba pokazywanych zbiorów i ich rodzaj, rzeczywista dostępność. Oto ich przegląd.

W 2013 roku w oddziale Muzeum Narodowego w Warszawie, w Muzeum Rzeźby w Królikarni udostępniono Magazyny Studyjne rzeźby XX/XXI wieku, nie traktując tego jako wystawę, lecz wybór do wieloaspektowych prezentacji, „tak zorganizowany magazyn, by publiczność podczas studyjnych wizyt (uprzednio jednak umówionych, p.m.) mogła z bliska zapoznać się z kolekcją Muzeum, porównać właściwości materiałów rzeźbiarskich, śledzić kierunki w sztuce ostatnich lat, a nawet podjąć własne studia rysunkowe” [www. krolikarnia.mnw.art.pl/kolekcje/magazyny, data odczytu: 05.02.2020].

Rzeczywisty magazyn nieco ponad 400 rzeźb udostępniany do studiów, to w pewnym stopniu nawiązanie do przedwojennej idei tzw. muzeów demonstracyjnych i laboratoryjnych ${ }^{5}$. Działania Muzeum Rzeźby w Królikarni miały jednak własne ciekawe preludium. Była to trwająca w dwóch

\footnotetext{
${ }^{5}$ Zarysowała ją Cezaria Baudouin de Courtenay-Ehrenkreutzowa [1933: 87-96], a rozwinęła i zrealizowała tę koncepcję Maria Znamierowska-Prüfferowa w założonym w 1959 r. Muzeum Etnograficznym w Toruniu (obecnie jej imienia). Magazyny zostały w nim podzielone na: demonstracyjne, do których mógł wejść każdy po wcześniejszym umówieniu, magazyny studyjne, w których przechowywano wybrane przedmioty w kontekstowym ujęciu i prowadzono zajęcia dla studentów i młodzieży szkolnej oraz magazyn poczekalnia, gdzie gromadzono obiekty przed konserwacją. Pewne „rozszerzenie magazynowe” miała także wielka wystawa rybołówstwa (w tamtych czasach „wizytówka” tego muzeum), zaopatrzo-
} 
odsłonach przez rok wystawa zatytułowana Skontrum ${ }^{6}$. Jak sugeruje tytuł był to pokaz stanu zbiorów, ale też ich braków (na drugą część wystawy kilkanaście prac wypożyczono z kolekcji prywatnych), w założeniu pokazujący życie zabytków ukryte dotąd przed publicznością. Było to równocześnie świadome zaprzeczenie jakiejkolwiek systematyki (czy to magazynowej, czy wystawowej), chodziło właśnie o gąszcz figur, o rodzaj „ekspresyjnej metainstalacji” - jak to określa w katalogu wystawy jej kuratorka [Tarasiuk 2013: 12]. Poszukiwanie własnych narracji pozostawiono widzom i to łączy ten udany eksperyment z „udostępnianiem magazynów”, do której to idei muzealnictwo z takim zapałem powraca. Królikarnia zrobiła to jako pierwsza, organizując dla publiczności przestrzeń magazynową z częścią kolekcji rzeźby współczesnej już w rok po wystawie Skontrum, a następnie także kolekcję Xawerego Dunikowskiego wraz z pracownią artysty. Przestrzeń, która udostępniania jest artystom do własnych układów i komentarzy, a z racji jednorodności kolekcji jest znakomitą platformą do dyskusji, wykładów, impresji. Rok później została otwarta „magazynowa” wystawa w Państwowym Muzeum Etnograficznym w Warszawie ${ }^{7}$.

W kolejnym, 2016 r. Narodowe Muzeum Morskie w Gdańsku oddało zwiedzającym swój nowy oddział: Centrum Konserwacji Wraków Statków wraz z Magazynem Studyjnym w Tczewie. W specjalnie zaprojektowanym budynku, dostosowanym dla wielkogabarytowych obiektów mieszczą się magazyny w postaci wielkiej nowoczesnej hali ekspozycyjnej z piętrowo umieszczonymi zabytkami dostępnymi dzięki specjalnym konstrukcjom z systemem wciągarek. Jest także przestrzeń dla muzealiów o mniejszych rozmiarach prezentowanych w przeszklonych, przesuwnych regałach. Dzięki aplikacjom mobilnym oraz stanowiskom komputerowym można uzyskać informacje o zabytkach i ich historii. Kolejna przestrzeń to pracownia konserwacji połączona komunikacyjnie z ekspozycją magazynową, ze specjalnej antresoli można bezpośrednio obserwować proces konserwacji

na np. w wysuwane szuflady, w których prezentowano kolejne warianty wystawionych przedmiotów. Taki układ funkcjonował jeszcze w latach siedemdziesiątych XX w.

${ }^{6}$ Wystawa w Muzeum Rzeźby w Królikarni, Oddział Muzeum Narodowego w Warszawie; Odsłona I: Skontrum 04.12.2011-15.04.2012, Odsłona II: Skontrum Ewolucje 18.05.-04.12.2012. Kurator Agnieszka Tarasiuk, współpraca Aleksandra Janiszewska, Michał Suchora.

${ }^{7}$ Tu także zaproszono do współpracy artystów, którzy przygotowali współczesne wersje dawnych, tradycyjnych wytworów rzemieślniczych, przedmiotów z kolekcji zbudowanej przez Piotra Szackiego. Celem interdyscyplinarnego projektu Uwolnić projekt było przywrócenie ludowym wytworom użyteczności w nowym świecie [www.ethnomuseum.pl/ projekty/uwolnic-projekt]. 
wraków [www.nmm.pl/centrum-konserwacji-wrakow-statkow/magazyn-studyjny, data odczytu: 05.02.2020].

Specjalnie zaprojektowaną przestrzeń nie tylko pod kątem aranżacji czy układu zbiorów, ale także warunków konserwatorskich oddało publiczności do normalnego zwiedzania w 2017 r. Muzeum Pałacu Króla Jana III w Wilanowie, pod nazwą Galeria Magazynowa w Markoniówce ${ }^{8}$. Było to możliwe dzięki odpowiedniej adaptacji pawilonu Markoniego, który przylega do pałacu, dzięki czemu wprost z ekspozycji można przejść do magazynów, a przy tym jest na tyle odrębną kubaturą, iż można było zadbać o stabilizację warunków odpowiednich dla zabytków. Było to tym ważniejsze, że Muzeum udostępnia kolekcję rzemiosła artystycznego bardzo zróżnicowaną i co za tym idzie wymagającą różnych gablot z mikroklimatem i całego muzealno-magazynowego entourage. Umożliwienie zwiedzania bez przewodnika wymagało dostarczenia widzowi podstawowych informacji o oglądanych dziełach. Gabloty mają więc swoje karty ze spisem wraz z metryczkami obiektów w nich zawartych. Wszystko trzyma się blisko rzeczy: rzemieślniczego kunsztu, konserwatorskiej profilaktyki i restauracji. Widoczne pracownie konserwatorskie są zgodnie z tą ideą usytuowane w tym samym budynku. Te założenia i cele szczegółowo opisuje Agnieszka Pawlak w artykule zamieszczonym na stronie Muzeum w Wilanowie [www.wilanow-palac.pl/magazyny_zbiorow_otwarte_dla_publicznosci_nowa_koncepcja_profilaktyki_muzealnej; odczyt: 05.02.2020], dorzucając także nieco ogólnych uwag dotyczących przestrzeni magazynowej w muzeach ${ }^{9}$. Mało znane aspekty dbałości o zabytkowe przedmioty przedstawia też popularny folder dostępny w Muzeum.

W końcu 2017 r. otworzyło swoje magazyny dla widzów Muzeum Historyczne Miasta Krakowa (obecnie Muzeum Krakowa) ${ }^{10}$, i to w sposób impo-

\footnotetext{
${ }^{8}$ Galeria Magazynowa w Markoniówce, kurator Agnieszka Pawlak, aranżacja Barbara Kowalewska.

${ }^{9} \mathrm{Nie}$ jest celem tego tekstu ocena ani recenzja przywołanych tu prezentacji czy artykułów, trudno jednak przemilczeć takie zdumiewające konstatacje autorki jak np.: „...w wielu mniejszych i gorzej finansowanych instytucjach, magazyny ciągle przypominają graciarnie, gromadzące nikomu już niepotrzebne przedmioty, niszczejące z upływem czasu w zapomnieniu” albo „nowoczesne muzeum musi odejść od koncepcji magazynu..., który jest jedynie cichym zapleczem lub miejscem „dogorywania” niepotrzebnych, zapomnianych przedmiotów”. Jeśli coś może zilustrować powiedzenie o strzelaniu sobie w stopę, to właśnie to, zwłaszcza na muzealnej witrynie.

${ }^{10}$ Thesaurus Cracoviensis. Centrum Interpretacji Artefaktów. Autorzy: Zespół opiekunów kolekcji i konserwatorów Muzeum Historycznego Miasta Krakowa pod kierunkiem Michała Niezabitowskiego, przy współpracy Bożeny Urbańskiej — kierownika magazynu zbiorów.
} 
nująco kompletny. Centralny magazyn wszystkich zbiorów tego muzeum powstał w odrębnym zaadoptowanym i przeprojektowanym budynku mieszczącym również pracownie konserwatorskie i digitalizacyjne. Zwraca uwagę również wielka dbałość o aranżację pomieszczeń, ze względu na jej kunsztowną niekiedy estetykę znakomicie podkreślającą charakter tematycznie ułożonych zbiorów. Ten magazynowy oddział Muzeum krakowskiego został nazwany Tezaurus Cracoviensis. Centrum Interpretacji Artefaktów, co wskazuje tyleż na zaufanie do erudycji publiczności, co zachętę do nawiązywania relacji z oglądanymi przedmiotami, relacji własnych lub stymulowanych przez przewodnika. Magazyn jest dostępny raz w tygodniu w grupach prowadzonych wytyczoną trasą, oferta ta ma być, w miarę rosnących doświadczeń, poszerzana. Oczywiście, konieczne są ograniczenia, wszystkie magazyny muzealne normalnie przecież „pracują”: prowadzone są ciągle wypożyczenia, kwerendy, prace porządkowe, kontrole stanu zbiorów. Stąd odpowiednio zaprojektowane oszklone gabloty, w przypadku na przykład szopek są jednocześnie pudłami transportowymi. Zadbano też o dostęp gości do elektronicznego katalogu zbiorów w sali multimedialnej, planowane są warsztaty i pokazy w sali spotkań. Ofertę edukacyjną, pracownie konserwatorskie i krótką charakterystykę poszczególnych kolekcji Muzeum prezentuje wydany katalog.

Jak wynika z krótkich opisów tych realizacji należy rozgraniczyć magazyny sensu stricto (Muzeum w Wilanowie, Muzeum Krakowa) od wystaw-magazynów (Muzeum Narodowe - Królikarnia w Warszawie, Muzeum Etnograficzne w Warszawie), co jednak nie wiąże się z rodzajem udostępnienia: ciągłym jak wszystkie inne wystawy (Etnograficzne, Wilanów) lub w wyznaczonych terminach (Kraków, Królikarnia). Specyficzne jest Muzeum w Tczewie, gdzie studyjny magazyn kolekcji szczególnego rodzaju obiektów oraz pokaz ich konserwacji zorganizowany jest w formie zwartej wystawy w odrębnym budynku zaprojektowanym dla tej kolekcji, z wykorzystaniem rozszerzonej rzeczywistości dla pokazania kontekstu zabytku.

Powracając, na tak zarysowanym tle, do wystawy-magazynu w Państwowym Muzeum Etnograficznym w Warszawie: prezentuje ona dość dużą (kilkutysięczną) kolekcję dotyczącą gospodarki podstawowej i rzemiosł, a więc całkowicie spoza sztuki (co oczywiście nie oznacza braku artystycznie wykonanych przedmiotów), jako jedyna przedstawia także założenia tej kolekcji, sposób jej budowania (dość specyficzny w przypadku obiektów etnograficznych) jej słowną i wizualną dokumentację oraz jej niematerialny 
kontekst. To oznacza, że cechą tej wystawy jest niedokończenie, czy raczej nieustanny rozwój, w miarę poszerzania badań, dokumentacji, cyfryzacji. Tak przynajmniej było w założeniach.

Już po otwarciu wystawy Muzeum podjęło próby działań w jej obszarze idące w innym kierunku. Udostępniona w sąsiedniej sali wystawa (w założeniu stała) Biblia Pauperum traktująca o chłopskiej interpretacji Biblii i ludowym pojmowaniu świata ${ }^{11}$ zaczyna się i „wchodzi” w wystawę „magazynową”. Figurom i obrazom o treści przeważnie religijnej, wstawionym pomiędzy przedmioty dnia codziennego towarzyszą tekstowe odwołania do biblijnych i apokryficznych wątków. Powiązane są z działami kolekcji: obróbką drewna, kowalstwem, transportem itd. Eksperyment być może interesujący, ale dla widza słabo czytelny, choćby dlatego, że nie wyjaśniony. Być może odbiór utrudniła kolejna wystawa (tym razem czasowa) jednocześnie (i ryzykownie - jako trzecia) usytuowana w tej samej przestrzeni: prywatna kolekcja „Maryjek” — barwnej rzeźby ludoweje' a być może brak wskazówek dla zwiedzających. O ich pewnym zdezorientowaniu świadczą wypełniane na wystawie ankiety (o tym za chwilę). Sławomir Sikora, były muzealnik, a więc niepozbawiony zawodowych kompetencji, autor celnych uwag i impresji związanych z wystawą magazynową Porządek rzeczy (zwiedzaną, kiedy „Maryjek” jeszcze nie pokazywano) podaje swoją interpretację częściowego nakładania się dwóch wystaw: urozmaicenie ekspozycji, niwelacja rozróżnienia na Sztukę i Rzemiosło, aluzja do sakralnego wymiaru pracy [Sikora 2017: 188]. O takim wymiarze ludzkich działań z pewnością mówi sąsiednia Biblia Pauperum, ale czy wprowadzone „do magazynu” jej akcenty są czytelne bez wyjaśnienia tego widzowi? Niemniej, muzeum jest także miejscem dla eksperymentów, doświadczenie je udoskonala i zamienia w dzieło akceptowane, czy może raczej zrozumiałe przez odbiorców. Jak zatem oni, najważniejsi, odebrali tę wystawę? Przyjemnie zaskakujące są wysokie oceny, tej nietypowej bądź co bądź, ekspozycji. Pomijając szczegółowe uznania, a nawet zachwyty nad przykładowo: krosnami tkackimi (bardzo wiele wpisów), przedmiotami z dziedziny kowalstwa czy pszczelarstwa, czy też (odosobnione) „odnajdywanie śladów kurpiowszczyzny”, zatrzymajmy się przy uwagach bardziej ogólnych. Podoba się nasycenie wystawy, natłok przedmiotów, możliwość

\footnotetext{
${ }^{11}$ Biblia Pauperum. Sztuka ubogich $i$ wykluczonych. Obraz Boga w sztuce ludowej. Zespół kuratorski: Paweł Matwiejczuk, Justyna Otwinowska, Amudena Rutkowska.

12 „Magnificat. Ludowy kalendarz maryjny w Polsce” Wystawa czasowa grudzień 2017- kwiecień 2018. Kolekcja Elżbiety Zajdel. Teksty w katalogu Elżbieta Zajdel, Paweł Matwiejczuk.
} 
zobaczenia ich różnych wariantów, „starego” obok „nowego”, połączenie form ozdobnych i prostych, zgromadzenie obok siebie różnych przedmiotów tego samego rodzaju, pokazanie „pomysłowości ludzi”. Widzowie zauważają też przejrzystość konstrukcji, „swoisty porządek”, a nawet „dekoracyjność porządku”, „wzory układające się z powtarzających się eksponatów”. Premiowane jest także „samodzielne poznawanie przez porównywanie” i to, że na wystawie „trzeba myśleć” lub że „może być punktem wyjścia do przemyśleń”. Wszystkie te uwagi zdają się potwierdzać kuratorskie intuicje, fenomenologiczny i semiotyczny potencjał wystawy. Są oczywiście także uwagi krytyczne, choć głównie techniczne. Przede wszystkim szwankowanie multimediów, a co za tym idzie trudność w dotarciu do szukanych informacji, lub zwyczajna wątłość niektórych opisów lub ich brak w udostępnianych dokumentacjach (zarzut niekoniecznie łatwy do skorygowania, przedmioty muzealne bywają też anonimowe). Umieszczenie wytworów sztuki ludowej na wystawie-magazynie podoba się nielicznym, ale są wśród nich entuzjaści, co najlepiej oddaje wpis: „Bóg jest w naszym codziennym życiu od zawsze. Inspiracja: nie zapominać o tym”. Postawę przeciwników tego eksperymentu najlepiej oddaje uwaga: „Tak, wystawa jest przejrzysta, tylko usuńcie stąd drugą nakładającą się ekspozycję sztuki, jest obca w stosunku do założeń wystawy”. Nie chodzi, rzecz jasna, o przesadne generalizacje na podstawie kilkuset ankiet, wystawę obejrzało już przecież tysiące ludzi. Otwarte jest pytanie, którzy z nich byli bardziej skłonni wypełnić ankietę, ci którym się podobała czy raczej odwrotnie. Korzystny dla autorów byłby ten drugi przypadek, negatywnych ocen (poza brakami technicznymi) właściwie nie było.

Na koniec ocena wystawy, która nas urzekła: „Jakby Kuśmirowski spotkał Wilkonia”. Cokolwiek to znaczy. Niech będzie wysłuchana i druga strona. Audiatur et altera pars.

\section{Bibliografia}

\section{Baudouin de Courtenay-Ehrenkreutzowa Cezaria}

1926: Wskazówki dla zbierajacych przedmioty dla Muzeum Etnograficznego Uniwersytetu Stefana Batorego $w$ Wilnie, Wilno: Pracownia Etnologii Uniwersytetu Stefana Batorego.

1933: Zakład Etnologii Uniwersytetu Stefana Batorego w Wilnie i jego zadania, „Balticoslavica”, t. 1, Wilno: Instytut Naukowo Badawczy Europy Wschodniej. 


\section{Chojnacki Krzysztof, Szacki Piotr,}

1989: Film etnograficzny, folder z Przeglądu Filmów Etnograficznych, Włocławek: Muzeum Ziemi Kujawskiej i Dobrzyńskiej.

\section{Czerni Krystyna}

brak daty: Kantor i mechanizmy pamięci [w:] Wirtualne Muzea Małopolski http://muzea. malopolska.pl/interpretacje/-/a/kantor-i-mechanizmy-pamieci; odczyt: 2.02.2019.

\section{Moszyński Kazimierz}

1928: Etnografia w muzeach regionalnych, Warszawa: Nasza Księgarnia.

\section{Piłsudski Bronisław}

1921: W sprawie Muzeum Tatrzańskiego. (O urzadzenie działu ludoznawczego), „Rocznik Podhalański”, t. 1, 1914-1921, Zakopane - Kraków.

\section{Sikora Sławomir}

2017: Porządek rzeczy. Magazyny Piotra B. Szackiego, „Zbiór Wiadomości do Antropologii Muzealnej”, nr 4.

\section{Sudjic Deyan}

2013: Język rzeczy, przeł. Adam Puchejda, Kraków: Karakter.

\section{Szacki Piotr}

1991: Refleksja o pruderii. O funkcjonowaniu pojęć w muzealnictwie etnograficznym, „Rocznik muzealny”, T. IV, Włocławek.

\section{Święch Jan, Tubaja Roman}

2001: Szkołyi kierunki w etnologii a muzealnictwo etnograficzne w Polsce [w:] Przeszłość etnologii polskiej w jej teraźniejszości, red. Z. Jasiewicz i T. Karwicka, Poznań.

\section{Tarasiuk Agnieszka}

2013: Skontrum w Muzeum Rzeźby, Warszawa: Muzeum Narodowe.

\section{Iwona Święch}

\section{On museum storeroom of things}

The article explores the author's thoughts on the artistic conception, scenario, and problems related to the permanent exhibition "The Order of Things. The storeroom of Piotr B. Szacki” held in the National Ethnographic Museum in Warsaw. The starting point is the collection related to primary economy and crafts, which was created by the Museum's staff member and remarkable museologist, Piotr Szacki. The article discusses how and why the Museum's storeroom that houses the collection has been transformed into an exhibition. Additionally, it outlines the background of the exhibition, including earlier collection models in ethnographic museology and similar exhibitions in Polish museums. Finally, the article outlines the activities around the already opened exhibition (not always well-received) and opinions of visitors.

Keywords: museology, collection, storeroom exhibition, objects, folk culture, video recording 